\title{
Effect of tillage methods and phosphorous fertilizer treatments on some physical properties and productivity of maize crop in calcareous soil
}

\author{
El-Kotb, H.M.A.*; Harvey, M. M.* and El-Edfawy, Y.M.* \\ *Soil, Water and Environment Research Institute, Agric., Res. Center, Giza (EGYPT) \\ E-mails: hasskotb@gmail.com, moheyharvey11@yahoo,com, Yasser_eledfawy@yahoo.com
}

\begin{abstract}
A field experiment was conducted along two successive seasons of summer (2014 and 2015) at El-Nubaria Agricultural Experimental Station of the Agricultural Research Center (A.R.C), west of Alexandria. The experiment was laid out to evaluate the effect of two tillage methods: conventional tillage (CT) and no-tillage (NT) and five phosphorous fertilizer treatments in sub plot as follows: $\mathrm{P}_{0}$ : without addition, $\mathrm{P}_{\mathrm{G} 1}: 240 \mathrm{~kg} \mathrm{ha}^{-1}, \mathrm{P}_{\mathrm{G} 2}$ : $480 \mathrm{~kg} \mathrm{ha}^{-1}$ as granular, $\mathrm{P}_{\mathrm{P} 1}: 240 \mathrm{~kg} \mathrm{ha}^{-1}$ and $\mathrm{P}_{\mathrm{P} 2}: 480 \mathrm{~kg} \mathrm{ha}^{-1}$ as powder on soil and maize plant ( Zea mays L.) .

Tillage methods affected increased of saturated hydraulic conductivity (Ksat) and total porosity (TP), decreased the bulk density of soil under conventional tillage (CT). Effects occurred in the three depths of the soil layers $(0-10),(10-20)$ and $(20-30) \mathrm{cm}$. The reduction percentages of bulk density values were $8.2,2.9$ and $4.9 \%$ for the three layers, respectively. Yields were increased under CT as compared to no NT. the harvest index was not significantly affected. There were differences in yield responding to phosphorus treatments. Under CT, granular P gave higher yields than powder P and the reverse occurred under NT. Phosphorous content and uptake of grain and straw were significantly affected by phosphorus treatments under both tillage methods. Conventional tillage increased $\mathrm{P}$ content and uptake in grain by 14 and $31 \%$ respectively, corresponding increase in $\mathrm{P}$ content and uptake in straw were 27 and $45 \%$ respectively. Under $\mathrm{CT}$, treatment $\mathrm{PG}_{2}$ recorded the highest values of $\mathrm{P}$ content and uptake in grain $\left(0.793 \%\right.$ and $\left.59.59 \mathrm{kgha}^{-1}\right)$. Corresponding increase in P content and uptake in straw were $0.330 \%$ and $36.79 \mathrm{kgha}^{-1}$. Under NT, the treatment $\mathrm{P}_{\mathrm{P} 2}$ was recorded the highest values $(0.777 \%$ and 52.56 $\mathrm{kg} \mathrm{ha}^{-1}$ ) for phosphorous content and uptake for grain only.
\end{abstract}

Key words: tillage methods; calcareous soil; granule; powder; P-fertilizer: maize

\section{Introduction}

Tillage management and fertilizers application are among the important factors affecting soil physical properties and crop yield. Maize is one of the most important cereal crops in Egypt and it is sown as a summer crop for human consumption, animal feeding and industrial purpose especially for oil and starch production.

One unique characteristic of $\mathrm{P}$ is its low availability due to slow diffusion and high fixation in soils. $\mathrm{P}$ can be a major limiting factor for plant growth, thus phosphorus is one of the major nutrients limiting agricultural production especially in calcareous soils. Chemical $\mathrm{P}$ fertilizers are added to increase crop production. In general, phosphorus deficiency is caused primarily by very low levels of total phosphorus and soil moisture (Marschner, 1995). Plant growth is affected by application of phosphorus (Gill et al., 1995; Kaya et al., 2001). The efficiency of $\mathrm{P}$ fertilizers in calcareous soils is generally very low because $\mathrm{P}$ applied to the soil reacts with $\mathrm{Ca}$ forming tri- calcium phosphate which not soluble (Tunesi et al., 1999 and Leytem and Mikkelsen, 2005). The availability of $\mathrm{P}$ to plants for uptake and utilization is impaired in alkaline and calcareous soil due to such effects. In general, phosphatic fertilizers are recommended to be broadcast and incorporated in soil before sowing (Malik, 1992). Fixation of broadcast $P$ is much greater than when fertilizers applied in bands because of narrow soil to fertilizer ratio in the latter situation. $\mathrm{P}$ availability depends on the production system used, including crop residue and fertilizer management, which is directly related to the type of tillage system used, conventional and no tillage (Tiecher et al., 2012; Mishra et al., 2012; Wyngaard et al., 2012). The chemical nature of soil $\mathrm{P}$ is also affected by tillage practice. $\mathrm{P}$ solubility is greater under conservation tillage, due to greater microbial activity during the decomposition of soil organic matter (Zibilske and Bradford, 2003). Tillage practices which mix the topsoil would also mix the previously applied $\mathrm{P}$, and thus increase the effectiveness of $\mathrm{P}$ fertilizer for subsequent crops (Bolland and Brennan, 2006).

No-tillage is a soil management system where a crop is planted directly into the soil with no primary or secondary tillage (SSSA, 2014). It is one of the conservational tillage methods. Conventional tillage is a system with a high degree of soil disturbance, involving the mixing of the surface layers of the soil, with the aim of controlling weeds and preparing a suitable soil condition for seed germination and crop growth (FAO, 2001). Tillage methods modify soil characteristics and control the vegetation factors (water, air, heat, nutritive elements and biological activity), thus facilitating optimal conditions for growth of plants. According to Robson and Taylor (1987) tillage practice can alter nutrients via 3 processes: (i) mixing nutrients through the soil and 
altering their 'availability' to the crop; (ii) changing the soil physical environment, which in influences root growth and function; and (iii) affecting soil biological activity. Soil plowing and rearrangement with clean surface from preceding crop residues and weeds is a technique, which aims at improving soil physical conditions for growth. Nevertheless, it causes reversible changes as water loss and organic matter decline. No and minimum tillage are considered as alternatives for soil tillage. No-tillage causes high bulk density and soil compaction, which negatively influence nutrients uptake with poor performance of root growth (Herridge and Holland, 1992). However it is advantageous over conventional tillage in some cases, (Francis, 1986). To alleviate such disadvantages and save time for sowing a crop, reduced tillage may be used as an alternative to no-till (Khalil, 1997; Nawar and Khalil, 2004). Conventional tillage reduces the soil mechanical resistance to plant-roots penetration, leading to deeper rooting system, which increases the uptake of growth resources, especially from the soil deeper layers and consequently, increased crop yield. El-Douby and Mohamed, (2002) reported that conventional tillage had a positive effect on faba bean seed yield. Despite seed yield reduction, the no tillage system could be effective in critical conditions, as the short-term period between two consecutive crops (Francis, 1986; Herridge and Holland, 1992)

Mechanical manipulation of soil during tillage may increase the chances of contact between soil solution and fertilizer-derived $\mathrm{P}$ and exposed soil particles and this facilitates the formation of insoluble $\mathrm{P}$ compounds (Hinsinger, 2001; Picone et al., 2003). Accumulation of organic matter and nutrients near the surface under reduced tillage may affect soil properties positively (Beare et al., 1997; Tebrugge and During, 1999). The aim of this study was to evaluate the effects of tillage methods and fertilizer phosphorus treatment applied to the calcareous soil on physical properties of soil, yield, and phosphorus in maize plant.

\section{Materials and Methods}

Two field experiments were conducted during the two successive seasons of 2014 and 2015 at the Agricultural Research Station (ARC), El-Behera Governorate, It is located at $30^{\circ} 54^{-}$latitude and $29^{\circ}$ $30^{-}$longitude. Its attitude is 22 meter above sea level, Egypt to study effect of tillage methods and phosphorous fertilizer treatments on some physical properties and productivity of maize crop grown in calcareous soil. At the beginning of this search work, soil samples from depth of (0-10), (10-20) and (20-30) $\mathrm{cm}$ were collected and analyzed, as Jackson (1975) and shown in Table 1.

The field experiment involved 10 treatments carried out in split - plot design with three replicates. The experiment included the following factors:

(A) Two tillage treatments as a main plot i.e. no tillage (NT) and conventional tillage (CT).

(B) Five phosphorous fertilizer treatments (single super phosphate $15.5 \% \mathrm{P}_{2} \mathrm{O}_{5}$ ) as a subplot as follows:

1- $\mathrm{P}_{0}$ : without addition

2- $\mathrm{P}_{\mathrm{G} 1}: 240 \mathrm{~kg} \mathrm{ha}^{-1}$ as granular.

3- $\mathrm{P}_{\mathrm{G} 2}: 480 \mathrm{~kg} \mathrm{ha}^{-1}$ as granular.

4- $\mathrm{P}_{\mathrm{p} 1}: 240 \mathrm{~kg} \mathrm{ha}^{-1}$ as powder.

5- $\mathrm{P}_{\mathrm{p} 2}: 480 \mathrm{~kg} \mathrm{ha}^{-1}$ as powder.

Table 1. Soil physical and chemical properties of the studied soil

\begin{tabular}{ccccccccccc}
\hline $\begin{array}{c}\text { Depth } \\
(\mathrm{cm})\end{array}$ & \multicolumn{2}{c}{ Particale size distribution $\%$} & Texture & $\begin{array}{c}\mathrm{CaCO}_{3} \\
(\%)\end{array}$ & $\begin{array}{c}\mathrm{O} . \mathrm{M} \\
\%\end{array}$ & $\begin{array}{c}\mathrm{BD} \\
\left(\mathrm{Mgm}^{-3}\right)\end{array}$ & $\begin{array}{c}\mathrm{TP} \\
(\%)\end{array}$ & $\begin{array}{c}\mathrm{K}_{\text {sat }} \\
(\mathrm{cm} / \mathrm{hr})\end{array}$ \\
\hline $0-10$ & 2.46 & 49.82 & 20.53 & 27.19 & Sandy clay loam & 28.66 & 0.61 & 1.44 & 38.72 & 4.54 \\
$10-20$ & 2.35 & 38.12 & 26.03 & 33.50 & Clay loam & 31.32 & 0.96 & 1.48 & 37.02 & 4.08 \\
$20-30$ & 2.07 & 50.41 & 22.22 & 25.30 & Sandy clay loam & 31.07 & 0.53 & 1.55 & 37.75 & 3.45 \\
\hline
\end{tabular}

C.S: Course Sand- F.S: Fine Sand- St: Silt- Cl: Clay- O.M: Organic Matter BD: Bulk density TP: total porosity Ksat: saturated hydraulic conductivity.

At CT treatment, P-fertilizer was mixed thoroughly with soil during soil preparation and before planting. While, at NT plots the P- fertilizer were applied on the soil surface without mixing. Maize seeds (Zea mayes L. c. v. single cross 10) were planted in into rows. Two seeds were planted in hill spaced at $20 \mathrm{~cm}$ between plants and $70 \mathrm{~cm}$ between rides. Two weeks after emergency plants were thinned to one plant/hill. All recommended agriculture practices except tillage and P-fertilization treatments of experiment were carried on. Nitrogen fertilizer was applied in the form of urea $(46 \% \mathrm{~N})$ as $626.4 \mathrm{~kg} \mathrm{ha}^{-1}$. Potassium sulfate $\left(48 \% \quad \mathrm{KO}_{2}\right)$ was applied before planting as $288 \mathrm{~kg} \mathrm{ha}^{-1}$. Phosphorus fertilizer was applied in the two types as: granular and powder in form of single super phosphate $\left(15.5 \% \mathrm{P}_{2} \mathrm{O}_{5}\right)$. Plants were harvested and separated into ears and straw. Dry weight of ears and straw of all plots were recorded. Calculations of $\mathrm{P}$ uptake were carried out using formula by Dobbermann (2005):

$\mathrm{P}$ - uptake $\left(\mathrm{kg} \mathrm{ha}^{-1}\right)=\mathrm{P}$ content $(\%)$ in plant part $\mathrm{x}$ dry weight $\left(\mathrm{kg} \mathrm{ha}^{-1}\right)$

Harvest index $(\%)=\left[\left(\right.\right.$ Grain yield $\left.\mathrm{kg} \mathrm{ha}^{-1}\right) /($ Grain + straw yield $\left.\left.\mathrm{kg} \mathrm{ha}^{-1}\right)\right] \times 100$

After harvest plant, disturbed and undisturbed soil samples of 0-10, 10-20 and 20-30 cm soil layers were collected for determination of soil properties as Black et al. (1965). 


\section{Result and discussion}

1. Effect of tillage methods and phosphorous fertilizer treatments on physical properties of calcareous soil.

\subsection{Bulk density (BD):}

Table 2 shows the effect of tillage methods and phosphorous treatments on the total average of soil bulk density (BD). The Results show that conventional tillage (CT) considerably decreased soil bulk density. This reduction occurred in the three depths of the soil layers. The averages of soil bulk densities as main effect of tillage were $1.34,1.36$ and $1.43 \mathrm{Mg} \mathrm{m}^{-3}$ for no-tillage (NT) and $1.23,1.32$ and $1.36 \mathrm{Mg} \mathrm{m}^{-3}$ for conventional tillage (CT) at the soil depth of (0-10), (10-20) and (20-30) cm, respectively. The reduction percentages of the conventional tillage (CT) were 8.2, 2.9 and $4.9 \%$ as compare with notillage (NT) for the three soil layers, respectively. In general, Bulk density of $20-30 \mathrm{~cm}$ soil depth was greater compared with that of $0-10 \mathrm{~cm}$ and $10-20 \mathrm{~cm}$ depths in both tillage methods. Lower bulk density obtained in conventional tillage (CT) than in no-tillage (NT) might be attributed to short term loosening effect of tillage and incorporation of crop residues into deeper soil Bhattacharyya et al., (2006). Dam et al (2005) found that bulk density of $0-10 \mathrm{~cm}$ was $10 \%$ higher in no-tillage $\left(1.37 \mathrm{Mg} \mathrm{m}^{-3}\right)$ than in conventional tillage (1.23 $\left.\mathrm{Mg} \mathrm{m}^{-3}\right)$. Kanwar (1989) and Meek et al (1992) reported that tillage methods altered bulk density and porosity of soils. Decreasing the number, intensity and depth of tillage caused higher bulk density. The increases in bulk density of the soil with no-tillage treatments have previously been reported by Xu and Mermoud (2001). Harvey (2012) and ElKotb (2013) who observed that the conventional tillage reduced bulk density. Prasad and Sinha (2000) and Khan et al. (2010) reported nonsignificant effect of inorganic fertilizers on soil bulk density. Bayu et al. (2006) reported that application of inorganic fertilizers had no significant effect on bulk density of the soil.

Table 2. Mean values of the studied soil physical properties as affected by tillage methods and phosphorous fertilizer treatments in calcareous soil

\begin{tabular}{|c|c|c|c|c|c|c|c|c|c|c|}
\hline \multirow{3}{*}{$\begin{array}{l}\text { Tillage } \\
\text { methods } \\
(\mathrm{T})\end{array}$} & \multirow{3}{*}{$\begin{array}{l}\text { Phosphorous } \\
\text { treatments } \\
\text { (P) }\end{array}$} & \multicolumn{3}{|c|}{ Bulk density (Mg m-3) } & \multicolumn{3}{|c|}{ Total porosity (\%) } & \multicolumn{3}{|c|}{$\begin{array}{l}\text { Hydraulic conductivity } \\
(\mathrm{cm} / \mathrm{hr})\end{array}$} \\
\hline & & \multicolumn{9}{|c|}{ Soil depth $(\mathrm{cm})$} \\
\hline & & $0-10$ & $10-20$ & $20-30$ & $0-10$ & $10-20$ & $20-30$ & $0-10$ & $10-20$ & $20-30$ \\
\hline \multirow{6}{*}{$\mathrm{CT}$} & $\mathrm{P}_{0}$ & 1.25 & 1.35 & 1.4 & 46.95 & 42.41 & 40.56 & 5.2 & 4.26 & 3.69 \\
\hline & $\mathrm{P}_{\mathrm{G} 1}$ & 1.25 & 1.33 & 1.37 & 46.81 & 43.4 & 41.56 & 5.13 & 4.37 & 3.78 \\
\hline & $\mathrm{P}_{\mathrm{G} 2}$ & 1.22 & 1.3 & 1.34 & 48.09 & 44.68 & 42.98 & 5.27 & 4.45 & 3.91 \\
\hline & $\mathrm{P}_{\mathrm{P} 1}$ & 1.24 & 1.32 & 1.36 & 47.23 & 43.83 & 42.13 & 5.22 & 4.36 & 3.83 \\
\hline & $\mathrm{P}_{\mathrm{P} 2}$ & 1.21 & 1.29 & 1.33 & 48.51 & 45.11 & 43.4 & 5.31 & 4.52 & 3.95 \\
\hline & Mean & 1.23 & 1.32 & 1.36 & 47.52 & 43.89 & 42.13 & 5.23 & 4.39 & 3.83 \\
\hline \multirow{6}{*}{ NT } & $\mathrm{P}_{0}$ & 1.37 & 1.41 & 1.46 & 41.7 & 39.86 & 37.87 & 4.57 & 4.02 & 3.45 \\
\hline & $\mathrm{P}_{\mathrm{G} 1}$ & 1.35 & 1.39 & 1.44 & 42.55 & 40.85 & 38.72 & 4.66 & 4.04 & 3.52 \\
\hline & $\mathrm{P}_{\mathrm{G} 2}$ & 1.32 & 1.36 & 1.41 & 43.83 & 42.13 & 40 & 4.8 & 4.16 & 3.64 \\
\hline & $\mathrm{P}_{\mathrm{P} 1}$ & 1.34 & 1.38 & 1.43 & 42.98 & 41.28 & 39.15 & 4.71 & 4.08 & 3.56 \\
\hline & $\mathrm{P}_{\mathrm{P} 2}$ & 1.31 & 1.35 & 1.4 & 44.26 & 42.41 & 40.43 & 4.85 & 4.19 & 3.68 \\
\hline & Mean & 1.34 & 1.36 & 1.43 & 43.06 & 41.31 & 39.25 & 4.72 & 4.1 & 3.57 \\
\hline \multirow{5}{*}{$\begin{array}{c}\text { Means } \\
\text { of }(P)\end{array}$} & $\mathrm{P}_{0}$ & 1.25 & 1.33 & 1.37 & 46.69 & 43.31 & 41.52 & 5.13 & 4.34 & 3.78 \\
\hline & $\mathrm{P}_{\mathrm{G} 1}$ & 1.27 & 1.34 & 1.38 & 46.06 & 43.09 & 41.26 & 5.06 & 4.31 & 3.75 \\
\hline & $\mathrm{P}_{\mathrm{G} 2}$ & 1.28 & 1.34 & 1.39 & 45.63 & 42.91 & 41.03 & 5.01 & 4.28 & 3.73 \\
\hline & $\mathrm{P}_{\mathrm{P} 1}$ & 1.29 & 1.35 & 1.4 & 44.9 & 42.42 & 40.49 & 4.93 & 4.22 & 3.68 \\
\hline & $\mathrm{P}_{\mathrm{P} 2}$ & 1.3 & 1.36 & 1.4 & 44.48 & 42.22 & 40.24 & 4.88 & 4.2 & 3.66 \\
\hline \multirow{3}{*}{ L.S.D 0.05} & $T$ & 0.02 & 0.01 & 0.01 & 0.68 & 0.32 & 0.42 & 0.07 & 0.09 & 0.04 \\
\hline & $P$ & n.s & n.s & n.s & n.s & n.s & n.s & n.s & n.s & n.s \\
\hline & $T * P$ & 0.05 & 0.11 & n.s & 2.36 & 4.76 & n.s & 0.23 & 0.38 & 0.26 \\
\hline
\end{tabular}

n.s: non-significant at the $5 \%$ levels of probability at L.S.D test. C.T $=$ Conventional tillage, N.T $=$ No tillage. $\mathrm{P}_{0}=$ without addition $\mathrm{P}_{\mathrm{G} 1}=240 \mathrm{kgha}^{-1}$ as granule $\mathrm{P}_{\mathrm{G} 2}=480 \mathrm{kgha}^{-1}$ as granule $\mathrm{PP} 1=240 \mathrm{kgha}^{-1}$ as powder, $\mathrm{P}_{\mathrm{P} 2}=480 \mathrm{kgha}^{-1}$ as powder.

\subsection{Total porosity (TP):}

Total porosity (TP) of soil is listed in Table 2 which shows that tillage methods had significant effects on the total soil porosity. Tillage practices showed that the CT had higher total porosity than NT. The increments of percentages of the conventional tillage were $10.36,6.25$ and $7.34 \%$ with no-tillage treatment in the three soil layers (0-10), (10-20) and
(20-30) cm, respectively. This is related to bulk density which decreased by (CT). Lipiec et al., (2006) reported that conventional tillage caused greater porosity El-Kotb, 2013 observed that tillage methods had significant effects on the physical properties of soil increasing total porosity and the main effect of $P$ was not significant. 


\subsection{Saturated hydraulic Conductivity ( $\left.K_{\text {sat }}\right)$ :}

The effects of tillage treatments and addition of $\mathrm{P}$ fertilizer on soil saturated hydraulic conductivity ( $\left.\mathrm{K}_{\text {sat }}\right)$ are shown in Table 2. Tillage had significant effects on soil hydraulic conductivity ( $\mathrm{K}_{\text {sat }}$ ). The values of $\mathrm{K}_{\text {sat }}$ of CT were greater than that of NT, this mean that tillage considerably increased hydraulic conductivity. This increment occurred in the three depths of the soil layer (0-10), (10-20) and (20-30) cm the average soil hydraulic conductivity were (4.72, 4.10 and 3.57) and (5.23, 4.39 and 3.83) $\mathrm{cm} / \mathrm{hr}$ with NT and CT, respectively. The increment percentages of the conventional tillage (CT) were 10.8, 7.0 and 7.3 $\%$ compare with NT for the three depths i.e. (0-10), $(10-20)$ and (20-30) cm. In general, hydraulic conductivity of (10-20) and (20-30) cm soil depths were lower compare with that of $(0-10) \mathrm{cm}$ depth in both tillage methods. Generally, the increase in bulk density with depth induced a decrease in hydraulic conductivity of subsurface soils. Some of results reported by others agree with the current results (Celik 2011). Heard et al., (1988) attributed the greater hydraulic conductivity in conventionally tilled soils to greater number of voids and cracks caused by the tillage implement. Kutilek and Nielsen (1994) and
Celik et al., (2010) reported that the soil compaction decreased saturated hydraulic conductivity in soils. High bulk density obtained by under no-tillage and reduced tillage methods was caused by soil compaction (Abu-Hamdeh 2003), and caused a low hydraulic conductivity obtained in no-tillage methods. El-Kotb (2013) observed that conventional tillage increases hydraulic conductivity as compared to minimum tillage and the main effect of $P$ treatments and the interactive effects between both tillage methods and $\mathrm{P}$ treatments on the average of hydraulic conductivity $\left(\mathrm{K}_{\text {sat }}\right)$ were no-significant trends.

\section{Effects of tillage methods and phosphorous fertilizer treatments on yields of grains, straw and grain + straw and Harvest Index of maize plants in calcareous soil: \\ Data in table (3) refer that, there are differences in yield responding to phosphorus treatments under both tillage methods. Under conventional tillage CT), the $\mathrm{P}_{\mathrm{G} 2}$ treatment (which added as a granular in full dose $480 \mathrm{~kg} \mathrm{ha}^{-1}$ ) recorded the higher responding values of yield and its components as compared to $\mathrm{P}_{0}$ (without phosphorous treatments).}

Table 3. Grain, straw, grain + Straw and harvest index of maize plants as affected by tillage methods and phosphorous fertilizer treatments in calcareous soil.

\begin{tabular}{|c|c|c|c|c|c|}
\hline \multirow{2}{*}{$\begin{array}{l}\text { Tillage } \\
\text { methods } \\
(\mathrm{T})\end{array}$} & \multirow{2}{*}{$\begin{array}{l}\text { Phosphorous } \\
\text { treatments } \\
\text { (P) }\end{array}$} & \multicolumn{3}{|c|}{ Yield $\left(\mathrm{kgha}^{-1}\right)$} & \multirow{2}{*}{$\begin{array}{l}\text { Harvest index } \\
\text { (\%) }\end{array}$} \\
\hline & & Grain & Straw & Grain + Straw & \\
\hline \multirow{6}{*}{ C.T } & $\mathrm{P}_{0}$ & 5805.6 & $\begin{array}{l}9398.4 \\
\end{array}$ & 15204.0 & 38.18 \\
\hline & $\mathrm{P}_{\mathrm{G} 1}$ & 6672.0 & 10192.8 & 16864.8 & 39.57 \\
\hline & $\mathrm{P}_{\mathrm{G} 2}$ & 7514.4 & 11145.6 & 18660.0 & 42.79 \\
\hline & $\mathrm{P}_{\mathrm{P} 1}$ & 6168.0 & 10046.4 & 16214.4 & 35.62 \\
\hline & $\mathrm{P}_{\mathrm{P} 2}$ & 7303.2 & 11049.6 & 18352.8 & 39.79 \\
\hline & Mean & 6693.6 & 10365.6 & 17059.2 & 39.19 \\
\hline \multirow{6}{*}{ N.T } & $\mathrm{P}_{0}$ & 5104.8 & 8272.8 & 13377.6 & 38.16 \\
\hline & $\mathrm{P}_{\mathrm{G} 1}$ & 5239.2 & 8316,0 & 13555.2 & 38.65 \\
\hline & $\mathrm{P}_{\mathrm{G} 2}$ & 6580.8 & 10176.0 & 16756.8 & 43.85 \\
\hline & $\mathrm{P}_{\mathrm{P} 1}$ & 5385.6 & 8424.0 & 13809.6 & 34.60 \\
\hline & $\mathrm{P}_{\mathrm{P} 2}$ & 6760.8 & 10411.2 & 17172.0 & 39.36 \\
\hline & Mean & 5815.2 & 9120.0 & 14935.2 & 38.93 \\
\hline \multirow{5}{*}{$\begin{array}{l}\text { Means of } \\
\text { (P) }\end{array}$} & $\mathrm{P}_{0}$ & 5455.2 & 8835.6 & 14290.8 & 38.17 \\
\hline & $\mathrm{P}_{\mathrm{G} 1}$ & 5955.6 & 9254.4 & 15210.0 & 39.11 \\
\hline & $\mathrm{P}_{\mathrm{G} 2}$ & 7047.6 & 10660.8 & 17708.4 & 43.32 \\
\hline & $\mathrm{P}_{\mathrm{P} 1}$ & 5776.8 & 9235.2 & 15012.0 & 35.11 \\
\hline & $\mathrm{P}_{\mathrm{P} 2}$ & 7032.0 & 10730.4 & 17762.4 & 39.58 \\
\hline \multirow{3}{*}{ L.S.D 0.05} & $T$ & 204 & 62.4 & 168 & 0.95 \\
\hline & $\boldsymbol{P}$ & 36 & 27 & 45 & 0.42 \\
\hline & $T * P$ & 51 & 37 & 57 & 0.57 \\
\hline
\end{tabular}

n.s: non-significant at the $5 \%$ levels of probability at L.S.D test. C.T $=$ Conventional tillage, N.T $=$ No tillage. $P_{0}=$ without addition $\mathrm{P}_{\mathrm{G} 1}=240 \mathrm{kgha}^{-1}$ as granule $\mathrm{P}_{\mathrm{G} 2}=480 \mathrm{kgha}^{-1}$ as granule $\mathrm{P}_{\mathrm{P} 1}=240 \mathrm{kgha}^{-1}$ as powder, $\mathrm{P}_{2}=480 \mathrm{kgha}^{-1}$ as powder.

The increment percentages were $29 \%, 19 \%, 23 \%$ and $12 \%$ for grain, straw, grain + straw yield and harvest index, respectively. While, in full dose of powder addition $\left(\mathrm{P}_{\mathrm{P} 2}\right)$ the responding values of yield and its components were less than that of $\mathrm{P}_{\mathrm{G} 2}$ treatment as compared to $\mathrm{P}_{0}$. The increment percentages were $(26 \%, 18 \%, 21 \%$ and $4 \%)$ for grain, straw, grain + straw yield and harvest index, respectively. This trend may be attributed to, under CT; P-fertilizer will be contacted with more of soil particles than under NT. On the other hand, soil particles will be mixed with the smaller particles area 
of P-fertilizer added as granular form as P-fertilizer added as powder. Thus, decrease in $\mathrm{P}$-fixation will be occurring. Utility of fertilizer to rapidly supply-P appears to be particle size dependent (Bauer et al., 2007), as has also been reported for water soluble $P$ fertilizer materials (Sander and Eghball, 1988). This is similar to results found in field study by Philip et al., (2012) who observed that many of the larger sized particles remained on the soil surface for the duration of the experiments.

Under no tillage method (NT), the addition of phosphorous in a powder form as a full dose $\left(\mathrm{P}_{\mathrm{p} 2}\right)$ recorded the higher values of responding to growth parameter as compared to $\left(\mathrm{P}_{0}\right)$. The increasing percent were $32 \%, 26 \%, 28 \%$ and $3 \%$ for grain, straw, grain + straw yield and harvest index, respectively. While, in full dose of granular addition $\left(\mathrm{P}_{\mathrm{G} 2}\right)$ the values of responding were $29 \%, 23 \%, 25 \%$ and $15 \%$ for grain, straw, grain + straw yield and harvest index, respectively. It seems to be less than powder form. This is due to that under no-tillage method (NT), Pfertilizer treatments were added on soil surface, so may be the solubility of phosphorous additions as a powder were higher than granular addition. So when the large particle size is used as a slow-release $\mathrm{P}$ source in conservation tillage methods may be sufficient $\mathrm{P}$ to meet plant requirements. This is similar to results found in earlier greenhouse research by Bauer et al., (2007). Philip et al., (2012) reported that the higher plant available $\mathrm{P}$ in the soil with the small particle size, it appears that if recovered calcium phosphate is used as a P-fertilizer source for conservation tillage production it should be applied as a small particle. As regard to effect of tillage methods, the results in Table 3 show that grain, straw and grain + straw yield under conventional tillage were significantly increased as compared to no tillage method whereas, the increment percentages were $15 \%, 14 \%$ and $14 \%$, respectively. Ranall et al., (2001) reported that the conventional methods produced significantly higher yields than no-till method. El kotb (2013) found that the maximum mean values were $856.93,1421.37$ and $2223.00 \mathrm{~kg}^{-}$ha $^{-}$ 1 for conventional tillage followed by 1709.11 , 3278.57 and $5120.4\left(\mathrm{~kg} \mathrm{ha}^{-1}\right)$ with minimum tillage for grain, straw and biological yields, respectively. Grain and biological yields were increased significantly in case of minimum tillage while, the observation of straw yield were non-significant increased. Harvey et al., (2015) reported that the results of conventional tillage have a considerable increase all yield characters as compared to reduced tillage.

As for the individual effect of the different $\mathrm{P}$ fertilization treatments, the results showed that grain, straw, grain + straw yield and harvest index \% were significantly affected by different P-fertilizers. Mean values of the data showed that the highest values were 7047.6. $\mathrm{Kg} \mathrm{ha}^{-1}$ and $43.32 \%$ for grain yield and harvest index and 10730.4 and $17762.4 \mathrm{~kg} \mathrm{ha}^{-1}$ for straw and grain + straw yield were produced by the treatments of $\mathrm{P}_{\mathrm{G} 2}$ and $\mathrm{P}_{\mathrm{P} 2}$, respectively. The lowest values $5455,8837,14292 \mathrm{~kg} \mathrm{ha}^{-1}$ and $38.17 \%$ for grain, straw, grain + straw yield and harvest index, respectively were produced by the treatment $\mathrm{P}_{0}$. the increments percentage of individual effect of $\mathrm{P}$ fertilizer treatments compared to $\mathrm{P}_{0}$ were shown in Table 4 generally, the increments of the studied yield parameters can be arranged in the descending order of: $\mathrm{P}_{\mathrm{G} 2}>\mathrm{P}_{\mathrm{P} 2}>\mathrm{P}_{\mathrm{G} 1}>\mathrm{P}_{\mathrm{P} 1}$. Whereas, $\mathrm{P}_{\mathrm{P} 2}$ recorded increment percentages of $29.21,20.64$ and $23.91 \%$. Increments percentages of $\mathrm{P}_{\mathrm{P} 1}$ were 28.91, 21.43 and $24.28 \%$.

Table 4. Increment percentages $(\%)$ in yields of grain, straw, grain + straw and harvest index at Phosphorous treatments as compared with non-P treated plants.

\begin{tabular}{|c|c|c|c|c|}
\hline \multirow{2}{*}{$\begin{array}{l}\text { Phosphorous } \\
\text { treatments } \\
\text { (P) }\end{array}$} & \multicolumn{3}{|c|}{ Yield $\left(\mathrm{kgha}^{-1}\right)$} & \multirow{2}{*}{ Harvest index $(\%)$} \\
\hline & Grain & Straw & Grain + Straw & \\
\hline P0 & - & 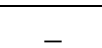 & - & - \\
\hline $\mathrm{P}_{\mathrm{G} 1}$ & 9.20 & $4 . \overline{7} 3$ & 6.43 & 2.46 \\
\hline $\mathrm{P}_{\mathrm{G} 2}$ & 29.21 & 20.64 & 23.91 & 13.49 \\
\hline $\mathrm{P}_{\mathrm{P} 1}$ & 5.89 & 4.51 & 5.04 & 8.02 \\
\hline $\mathrm{P}_{\mathrm{P} 2}$ & 28.91 & 21.43 & 24.28 & 3.69 \\
\hline
\end{tabular}

$\mathrm{P}_{\mathrm{G} 1}$ increments percentages recorded 9.2, 4.37 and $6.43 \%$. The lowly increments were recorded with treatment $\mathrm{P}_{\mathrm{P} 1}$ and where 5.89, 4.51 and $5.04 \%$ for grain, straw, grain + straw respectively. Ali et al. (2002) reported significant effect of $P$ application on grain yield. Amanulla and Zakirullah (2010) reported that levels and time of $\mathrm{P}$ application had significant effects on ear length, number of rows, grains per ear, and grain weight of maize. Masood et al., (2011) stated that grain yield was significantly affected by different levels of phosphorous. Mean values of the data showed that maximum grain yield $\left(2415 \mathrm{~kg} \mathrm{ha}^{-1}\right)$ was produced by the treatments of 240 $\mathrm{kg} \mathrm{P}_{2} \mathrm{O}_{5} \mathrm{ha}^{-1}$, followed by $360 \mathrm{~kg} \mathrm{P}_{2} \mathrm{O}_{5} \mathrm{ha}^{-1}(2027 \mathrm{~kg}$ ha $\left.^{-1}\right)$. Ahmad et al., (2013) reported that maize plant height, number of cobs plot ${ }^{-1}$, grain and biomass yields increased with increasing levels of phosphorus.

\section{Effect of tillage methods and phosphorous fertilization treatments on phosphorous content and uptake of maize in calcareous soil.}


The data presented in Table 5 showed that there are differences in phosphorous content and uptake of grain and straw for P-fertilizer treatments under tillage methods. Under CT, P-fertilizers which added as granular in full dose $\left(\mathrm{P}_{\mathrm{G} 2}\right)$ recorded the highest values $(0.793$ and $0.330 \%)$ for content and (59.59 and 36.79 $\mathrm{kg} \mathrm{ha}^{-1}$ ) for uptake of grain and straw, respectively while, the lowest values $(0.533$ and $0.160 \%)$ for content and (30.96 and $\left.15.05 \mathrm{~kg} \mathrm{ha}^{-1}\right)$ for uptake were recorded in treatment $\mathrm{P}_{0}$ (without phosphorous addition), of grain and straw respectively. In general, P-fertilizers in a granular form enhance phosphorous content and uptake (in both grain and straw) compared to powder addition.

Under no tillage (NT), full dose of P-fertilizer as powder $\left(\mathrm{P}_{\mathrm{p} 2}\right)$ recorded the highest values of phosphorous content and uptake $(0.777 \%$ and 52.56 $\left.\mathrm{kg} \mathrm{ha}^{-1}\right)$ in grain while, the lowest values $(0.193 \%$ and $\left.16.00 \mathrm{~kg} \mathrm{ha}^{-1}\right)$ for P-content and uptake of straw were recorded in treatment of without phosphorous addition $\left(\mathrm{P}_{0}\right)$. In conventional tillage $(\mathrm{CT})$, the added $\mathrm{P}$ fertilizer were mixed with the soil so, may be due to, the soil particles were contacted with the smaller surface area of phosphorous particles as granular than as powder addition and decrease in phosphorous fixation process and increase availability. While, in no tillage method (NT), phosphorus fertilizer added on soil surface so, may be the solubility of powder were higher than granular and increase plant phosphorous absorption. Utility of fertilizer to rapidly supply $\mathrm{P}$ appears to be particle size dependents (Bauer et al., 2007), as has also been reported for water soluble $P$ fertilizer materials Sander and Eghball, (1988). This is similar to results found in field study by According to Bortolon et al. (2010) who reported that tillage practices and soil amendments play a key role in $\mathrm{P}$ dynamics and distribution in soils and eventually $\mathrm{P}$ uptake by plants.

As regard to effect of tillage method, the results in table 5 show that, $\mathrm{P}$-content and uptake of grain and straw were significantly increase under conventional tillage (CT) as compared to no tillage. The increment values of content for conventional tillage method as compared to (NT) as a percentage were 14 and $27 \%$ while, the increment values of uptake were 31 and 45 $\%$ for grain and straw, respectively. Lynch (1995), reported that the absorption of $\mathrm{P}$ by plants is enhanced by tillage practices. This might have caused a higher $\mathrm{P}$ uptake under conventional tillage (CT) relative to no-tillage (NT). Under the NT method, nutrient stratification of the top $0-15 \mathrm{~cm}$ layer of the soil could have resulted in the lower $\mathrm{P}$ uptake due to the lower mobility of phosphorus in the soil.

Table 5. phosphorous of maize plants as affected by tillage methods and phosphorous fertilizer treatments in calcareous soil.

\begin{tabular}{|c|c|c|c|c|c|}
\hline \multirow{2}{*}{$\begin{array}{l}\text { Tillage } \\
\text { methods } \\
(\mathrm{T})\end{array}$} & \multirow{2}{*}{$\begin{array}{l}\text { Phosphorous } \\
\text { treatments } \\
\text { (P) }\end{array}$} & \multicolumn{2}{|c|}{$\mathrm{P}$ - content $(\%)$} & \multicolumn{2}{|c|}{ P- uptake (kg ha-1) } \\
\hline & & Grain & Straw & Grain & Straw \\
\hline \multirow{6}{*}{ C.T } & $\mathrm{P}_{0}$ & 0.533 & 0.160 & 30.960 & 15.048 \\
\hline & $\mathrm{P}_{\mathrm{G} 1}$ & 0.767 & 0.267 & 51.192 & 27.288 \\
\hline & $\mathrm{P}_{\mathrm{G} 2}$ & 0.793 & 0.330 & 59.592 & 36.792 \\
\hline & $\mathrm{P}_{\mathrm{P} 1}$ & 0.753 & 0.247 & 46.488 & 24.792 \\
\hline & $\mathrm{P}_{\mathrm{P} 2}$ & 0.767 & 0.300 & 55.920 & 33.120 \\
\hline & Mean & 0.723 & 0.261 & 48.840 & 27.408 \\
\hline \multirow{6}{*}{ N.T } & $\mathrm{P}_{0}$ & 0.543 & 0.193 & 27.768 & 16.008 \\
\hline & $\mathrm{P}_{\mathrm{G} 1}$ & 0.570 & 0.207 & 29.832 & 17.280 \\
\hline & $\mathrm{P}_{\mathrm{G} 2}$ & 0.667 & 0.220 & 43.896 & 22.392 \\
\hline & $\mathrm{P}_{\mathrm{P} 1}$ & 0.613 & 0.200 & 33.024 & 16.872 \\
\hline & $\mathrm{P}_{\mathrm{P} 2}$ & 0.777 & 0.210 & 52.560 & 21.840 \\
\hline & Mean & 0.634 & 0.206 & 37.272 & 18.888 \\
\hline \multirow{5}{*}{ Means of $(\mathrm{P})$} & $\mathrm{P}_{0}$ & 0.538 & 0.160 & 29.364 & 15.528 \\
\hline & $\mathrm{P}_{\mathrm{G} 1}$ & 0.669 & 0.237 & 40.512 & 22.284 \\
\hline & $\mathrm{P}_{\mathrm{G} 2}$ & 0.730 & 0.330 & 51.744 & 29.592 \\
\hline & $\mathrm{P}_{\mathrm{P} 1}$ & 0.683 & 0.224 & 39.756 & 20.832 \\
\hline & $\mathrm{P}_{\mathrm{P} 2}$ & 0.772 & 0.255 & 54.240 & 27.480 \\
\hline \multirow{3}{*}{ L.S.D 0.05} & $\mathbf{T}$ & 0.016 & 0.008 & 0.440 & 0.350 \\
\hline & $\mathbf{P}$ & 0.025 & 0.012 & 0.700 & 0.550 \\
\hline & $\mathbf{T} * \mathbf{P}$ & 0.035 & 0.017 & 0.980 & 0.780 \\
\hline
\end{tabular}

n.s: non-significant at the $5 \%$ levels of probability at L.S.D test. C.T $=$ Conventional tillage, N.T $=$ No tillage. $P_{0}=$ without addition $\mathrm{P}_{\mathrm{G} 1}=240 \mathrm{kgha}^{-1}$ as granule $\mathrm{P}_{\mathrm{G} 2}=480 \mathrm{kgha}^{-1}$ as granule $\mathrm{P}_{\mathrm{P} 1}=240 \mathrm{kgha}^{-1}$ as powder, $\mathrm{P}_{\mathrm{P} 2}=480 \mathrm{kgha}^{-1}$ as powder.

Regardless tillage method, the individual effect of the experimental used P-fertilizers on P-content and uptake by grain and straw, data shows that the Pcontent and uptake in grain and straw were significantly affected by different P-fertilizer treatments. There are significant increases in $\mathrm{P}$ content and uptake of grain and straw due to increasing the $\mathrm{P}$ - application rate. The maximum 
individual values $\left(0.772 \%\right.$ and $\left.54.24 \mathrm{~kg} \mathrm{ha}^{-1}\right)$ were recorded for $\mathrm{P}_{\mathrm{P} 2}$ treatment in grain and $(0.275 \%$ and $\left.29.59 \mathrm{~kg} \mathrm{ha}^{-1}\right)$ were recorded for $\mathrm{P}_{\mathrm{G} 2}$ treatment in straw for content and uptake, respectively. The minimum values of P-content and uptake $(0.538 \%$ and $29.36 \mathrm{~kg}$ $\left.\mathrm{ha}^{-1}\right)$ in grain and $\left(0.160 \%\right.$ and $\left.15.53 \mathrm{~kg} \mathrm{ha}^{-1}\right)$ in straw, respectively were observed in the treatment $\mathrm{P}_{0}$. The increments percentage of $\mathrm{P}$-fertilizer effect compared to $\mathrm{P}_{0}$ were shown in Table 6 . The data refer that all the
P-fertilization treatments, P-content and uptake recorded significant increases as compared to $\mathrm{P}_{0}$. The highest increment values of $\mathrm{P}$-content were noticed in treatment $\mathrm{P}_{\mathrm{G} 2}$ for straw while, in grain were in treatment $\mathrm{P}_{\mathrm{p} 2}$. The same trend was noticed with $\mathrm{P}$ uptake. These results are in agreement with Alam et al., (2003), Ezekiel and Adigun (2005), Laghari et al.(2010) and Saha et al., (2014).

Table 6. Increment percentages (\%) in P-content and uptake in grain and straw at Phosphorous treatments as compared to non-P treated plants.

\begin{tabular}{|c|c|c|c|c|}
\hline \multirow[b]{2}{*}{$(\mathrm{P})$} & \multicolumn{2}{|c|}{ content $\%$} & \multicolumn{2}{|c|}{ uptake (kg ha-1) } \\
\hline & Grain & Straw & Grain & Straw \\
\hline $\mathrm{P}_{0}$ & --- & --- & --- & --- \\
\hline $\mathrm{P}_{\mathrm{G} 1}$ & 24 & 34 & 91.2 & 98.4 \\
\hline $\mathrm{P}_{\mathrm{G} 2}$ & 36 & 56 & 148.8 & 218.4 \\
\hline $\mathrm{P}_{\mathrm{P} 1}$ & 26 & 26 & 115.2 & 81.6 \\
\hline $\mathrm{P}_{\mathrm{P} 2}$ & 45 & 45 & 204.0 & 184.8 \\
\hline
\end{tabular}

$\mathrm{P}_{0}=$ without addition. $\mathrm{P}_{\mathrm{G} 1}=240 \mathrm{kgha}^{-1}$ as granule $\mathrm{P}_{\mathrm{G} 2}=480 \mathrm{kgha}^{-1}$ as granule, $\mathrm{P}_{\mathrm{P} 1}=240 \mathrm{kgha}^{-1}$ as powder, $\mathrm{P}_{\mathrm{P} 2}=480 \mathrm{kgha}$ ${ }^{1}$ as powder.

\section{References}

Abu-Hamdeh; N. H. 2003. Soil compaction and root distribution for okra as affected by tillage and vehicle parameters. Soil and tillage research 74(1): 25-35.

Ahmad, M.; Khan, M. J. and Muhammad, D. 2013. Response of maize to different phosphorus levels under calcareous soil conditions. J. Agric. (29):2013-2021.

Alam, S. M.; Shah, S. A. and Akthar M., 2003. Varietal differences in wheat yield and phosphorus application. Songklanakarin J. Sci. Technol. 25(2):175-181.

Ali, J.; Bakht, J.; Shafi, M.; Khan S. and Shah. W. A. 2002. Uptake of nitrogen as affected by various combinations of nitrogen and phosphorus. Asian J. Pl. Sci. 1: 367-369.

Amanullah and Zakirullah, M. 2010. Timing and rate of phosphorus application influence maize phenology, yield and profitability in Northwest Pakistan. Acad. J. biolog. Sci. 1(1): 29-39. as influenced by tillage methods. Soil Till. Res. 89 (2006) 210-220.

Bauer, P. J.; Szogi, A. A. and Vanotti, M. B. 2007. Agronomic effectiveness of calcium phosphate recovered from liquid swine manure. Agron. J. 99:1352-1356.

Bayu, W.; Rethman, N. F. G.; Hammes, P. S. and Alemu. G. 2006. Application of farmyard manure improved the chemical and physical properties of the soil in a semi-arid area in Ethiopia," Biological Agriculture and Horticulture 24(3): 29 -300.

Beare, M. H.; Hu, S.; Coleman, D. C. and Hendrix, P.F. 1997. Influences of mycelial fungi on soil aggregation and organic matter storage in conventional and no-tillage soils. Appl. Soil Ecol. 5: 211-219.

Bhattacharyya, R.; Prakash, V.; Kundu, S. and Gupta, H. S. 2006. Effect of tillage and crop rotations on pore size distribution and soil hydraulic conductivity in sandy clay loam soil of the Indian Himalayas. Soil and Till. Res. 86(2): 129-140

Black, C. A.; Evans, D. D.; Ensmininger, L. E.; White, J. L. and Clark, F.E. 1965. Methods of soil analysis - Part II. Americ. Soci. Agron. Inc., Publisher. Madison, Wisconsin, USA.

Bolland, M. D. A. and Brennan, R. F. 2006. Phosphorus, copper and zinc requirements of notill wheat crops and methods of collecting soil samples for soil testing. Australian J. Exp Agric 46: 1051-1059.

Bortolon, L.; Kovar, J .L.; Cambardella, C. A.; Singer, J. W. and Gianello, C. 2010. 19th World Congress of Soil Science, Soil Solutions for a Changing World. 1 - 6 August 2010. Brisbane, Australia.pp.241-244.

Celik, I. 2011. Effects of tillage methods on penetration resistance, bulk density and saturated hydraulic conductivity in a clayey soil conditions. J. Agric. Sci. 17: 143-156. 
Celik, I.; Gunal, H.; Budak, M. and Akpinar, C. 2010. Effects of long-term organic and mineral fertilizers on bulk density and penetration resistance in semiarid Mediterranean soil conditions. Geoderma 160(2): 236-243.

Dam, R. F.; Mehdi, B. B.; Burgess, M. S. E.; Madramootoo, C. A.; Mehuys, G. R. and Callum, I. R. 2005. Soil bulk density and crop yield under eleven consecutive years of corn with different tillage and residue practices in a sandy loam soil in central Canada. Soil and Till. Res. 84: 41-53

Dobbermann, A. 2005. Nitrogen use efficiency-state of the art. IFA International workshop on enhanced-efficiency fertilizers. Frankfurt, Germany. June 28-30.

EL-Douby, K. A. and Mohamed, S.G.A. 2002. Effect of tillage, phosphorus fertilization and weed control on faba bean and estimation of the contribution of yield components statistically. Egypt J. Agric. Res. 80: 253-274.

El-Kotb, H. M. A. 2013. Combination effects of tillage methods and organic manures on some physio-chemical properties of calcareous soil and faba bean productivity. New York Sci. J. 6(12): 193-202.

Ezekiel, A. A. and Adigun, I. O. 2005. Phosphorususe efficiency by pepper (Capsicum frutescens) and Okra (Abelmoschus esculentum) at different phosphorus fertilizer application levels on two tropical soils. J. Applied Sci. 5(10): 1785-1791.

FAO. 2001. Guidelines and reference materials for promoting integrated soil and nutrient management in farmer field schools. Reference material for the module on tillage. Draft. FAO, Land Pl. Nutr. Man. Service, Land and Water Development Division FAO, Rome Italy.

Franchini, J. C.; Miyazawa, M.; Pavan, M.A. and Malavolta, E. 1999. Ion dynamic in acid soil leached with green manure extracts and organic acids. Pesquisa Agropecuária Brasileira 34: 2267 2276.

Francis, C. A., 1986. Distribution and importance of multiple cropping, pp: 1-20. Multiple Cropping Methods, Chapter 1, Macmillan publishing, Newyork, USA.

Gill, M. P. S.; Dhillon, N. S. and Dev, G. 1995. Phosphorous requirement of pearl millet and sorghum fodder as affected by native fertility of arid brown soil. Ind. J. Agric. Res., 29: 83-8

Harvey, M. M. 2012. Effect of different soil managements on some chemical and physical properties of El-Nubaria soils.Ph.D. Faculty of Agriculture Benha Univ., Egypt.

Heard, J. R.; Kladivko, E. J. and Mannering, J. V. 1988. Soil macroporosity, hydraulic conductivity and air permeability of silty soils under long-term conservation tillage in Indiana. Soil Till. Res. 11(1): $1-18$
Herridge, P. F. and Holland, J. C. 1992. Production of summer crops in northern New South Wales. I. Effect of tillage and double cropping on growth, grain yield and N-levels of six crops. Aust. J. Agric. Res., 43: 105-122.

Hinsinger, P. 2001. Bioavailability of soil inorganic $\mathrm{P}$ in the rhizosphere as affected by root-induced chemical changes: a review. Plant Soil 237: 173195.

Jackson M. L. 1973. Soil Chemical Analysis. Prentice-Hall, Englewood Cliffs. New Jersey.

Kanwar, R. S. 1989. Effect of tillage system on the variability of soil water tensions and water content. Trans. ASAE 32(2): 605-610.

Kaya, C.; Higgs, D. and Kimak, H. 2001. The effect of high salinity $(\mathrm{NaCl})$ and supplementary phosphorous and potassium on physiology and nutrition development of spinach. Bulg. J. Plant Physiol. 27: 47-59

Khalil, H. E. 1997. Evaluation of agronomic and economic aspects of sunflower under soil tillage practices and phosphorus application. Adv. Agric. Res. 2: 67-78.

Khan, N. I.; Malik, A. U.; Umer F. and Bodla, M. I. 2010. Effect of tillage and farm yard manure on physical properties of soil, Int. Res. J. Pl. Sci. 1 (4): 75-82.

Kutilek, M. and Nielsen, D. R. 1994. Soil Hydrology. Catena Verlag, Cremlingen-Destedt, Germany.

Laghari, G. M.; Oad, F. C.; Tunio, S. D.; Gandahi, A. W.; Siddiqui, M. H.; Jagirani, A. W. and Oad, S. M. 2010. Growth yield and nutrient uptake of various wheat cultivars under different fertilizer regimes. Sarhad J. Agric. 26 (4): 489497.

Leytem, A. B. and Mikkelsen, R. L. 2005. The nature of phosphorus in calcareous soils. Better Crops. 89. 2:11-13.

Lipiec, J.; Kus J.; Słowin'ska-Jurkiewiczc, A. and Nosalewicz, A. 2006. Soil porosity and water infiltration

Lynch, J. 1995. Root architecture and plant productivity. Pl. Physiol. 109: 7-13.

Malik, D. M. 1992. Phosphorus management for wheat production in Punjab. Proceeding Symposium on the Role of Phosphorus in Crop Production. NFDC, Islamabad. pp: 175- 196.

Marschner, H. 1995. Mineral nutrition of plants (2nd Ed.). Academic Press Ltd., London, UK.

Meek, B. D.; Rechel, E. A.; Cater, L. M.; DeTar, W. R. and Urie, A. L. 1992. Infiltration rate of a sandy loam soil: effets of traffic, tillage, and plant roots. Soil Sci. Soc. of Am. J. 56: 908-913.

Mishra, A.; Cabrera, M. L. and Rema, J. A. 2012. Phosphorus fractions in poultry litter as affected by flue-gas desulphurization gypsum and litter stacking. Soil Use Manage., 28:27-34, 2012.

Mosood, T.; Gul, R.; Munsif, F.; Jalal, F.; Hussain Z.; Noreen N.; Khan, H. Nasiruddin and Khan, 
H. 2011. Effect of different phosphorus levels on the yield and yield components of maize. Sarhad J. Agric. Vol. 27: No.2: 167-170, 2011.

Nawar, A. I. and Khalil, H. E. 2004. Evaluation of some agronomic and economic aspects of faba bean (Vicia faba L.) under different soil tillage methods and bio-and chemical phosphorus fertilization. Adv. Agric. Res. 9: 593-666

Philip, J. B.; Ariel, A. S.; Jeff, M. N.; Matias, B. and Vanott,i P. J. 2012. Phosphorus Recovered From Swine Wastewater as a Fertilizer for Cotton Grown With Conservation Tillage. J. Cott. Sci. 16: 97-104

Picone, L. I.; Zamuner, E. C.; Berardo, A. and Marino, M. A., 2003. Phosphorus transformations as affected by sampling date, fertilizer rate and phosphorus uptake in a soil under pasture. Nutr. Cycl. Agroecosyst. 67: 225-232.

Prasad, B. and Sinha, S. K. 2000. "Long-term effects of fertilizers and organic manures on crop yields, nutrient balance, and soil properties in ricewheat cropping system in Bihar," In: I. P. Abrol, K. F. Bronson, J. M. Duxbury and R. K. Gupta, Eds., Long-term soil fertility experiments in ricewheat Cropping Methods. Rice-Wheat Consortium Paper Series 6, Rice-Wheat Consortium for the Indo-Gangetic Plains, New Delhi, 2000, pp. 105-119.

Ranall, G. W.; Vetsch, J. A. and Murrell, T. S. 2001. Corn response to phosphorus placement under various tillage practices. Better Crops 85 (3): 1785.1791.

Robson, A. D.; Taylor, A. C. 1987. The effect of tillage on chemical fertility of soil. In (Eds), P.S Cornish and J.E. Pratley 'Tillage: new directions in agriculture'. (Eds) pp. 284-307.

Saha, S.; Saha, B.; Mirmu, S.; Pati, S. and Roy, D. 2014. Grain yield of phosphorus uptake by wheat as influenced by long-term phosphorus fertilization. African Journal of Agricultural Research 9 (6): 607-612.

Sander, D. H. and Eghball, B. 1988. Effect of fertilizer phosphorus particle size on phosphorus fertilizer efficiency. Soil Sci. Soc. Am. J. 52:868873.

Schlindwein, J. A., and Anghinoni, I. 2000. Vertical variability of available phosphorus and potassium and soil sampling depth under no-till. Ciência Rural 30: 611-617.

SSSA (Soil Science Society of America). 2014. Glossary of soil science terms. Retrieved from https://www.soils.org/publications/soils-glossary. Assess date: 20th September, 2014.

Tebrugge, F. and During, R. A. 1999. Reduced tillage intensity: A review of results of a long-term study in Germany. Soil Till. Res. 53: 15-28.

Tiecher, T.; Rheinheimer, D. S.; Kaminski, J. and Calegari, A. 2012. Forms of inorganic phosphorus in soil under different long term soil tillage methods and winter crops. R. Bras. Ci. Solo 36:271-281.

Tunesi, S.; Poggi, V. and Gessa, C. 1999. Phosphate adsorption and precipitation in calcareous soils: The role of calcium ions in solution and carbonate minerals. Nutr. Cycling Agroecosyst. 53:219-227.

Wyngaard, N.; Eecheverrìa, H. E.; Vidaurreta, A.; Picone, L. I. and Divito, G. A. 2012. Carbon and phosphorus in soil particulate fraction: Effect of continuous agriculture, tillage and fertilization. Geophys. Res. Abstr. 14:3377- 3390.

Xu, D. and Mermoud, A. 2001. Topsoil properties as affected by tillage practices in North China. Soil Till.Res. 60(1): 11-19.

Zibilske L. M; and Bradford J. M. 2003. Tillage effects on phosphorus mineralization and microbial activity. Soil Science 168, 677-685. 


\section{تأثير نظم الحرث والتسميد الفوسفاتى على بعض خواص الارض الطبيعية وإنتاجية محصول الذرة الثامية فى الأرض الجيرية \\ حسن محمد أحمد القطب - محيى محب هرفى - ياسر محمد الإدفاوى \\ معهد بحوث الأراضى والمباه والبيئة - مركز البحوث الزراعية- الجيزة}

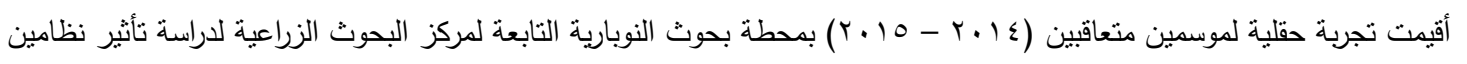

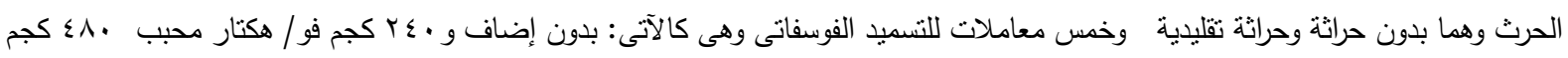

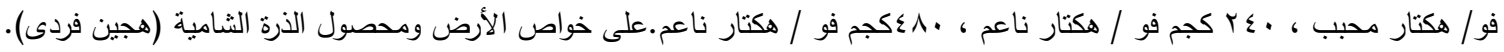

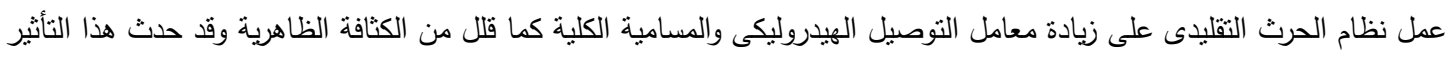

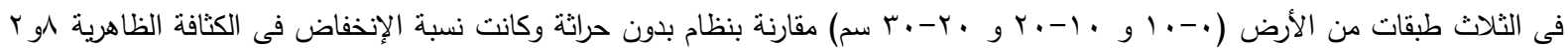
و rو 9 و و 9 \% مقارنة بنظام بدون حراثة. عمل نظام الحراثة التقليدية على زيادة المحصول مقارنة بنظام بدون حراثة في حين كانت الزيادة فئن في دليل الحصاد زيادة غير معنوية .

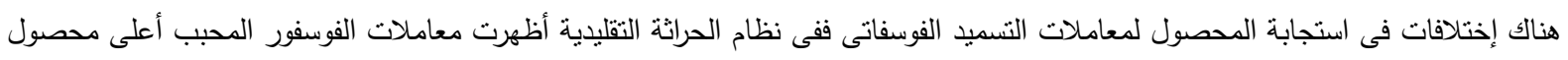
مقارنة بمعاملات الفوسفور الناعم كما حدث العكس فى نظام بدون حراثة إنة زاد محتوى النبات من الفوسفور والكمية الممتصة فى الحبوب والقش بزيادة معدل التسميد الفوسفاتى زيادة معنوية فى كلا نظامى الحرث

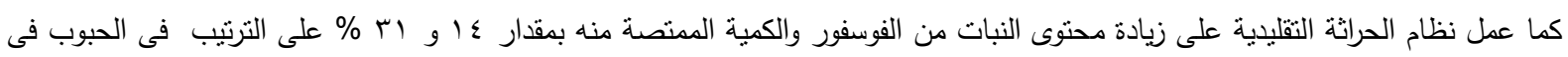

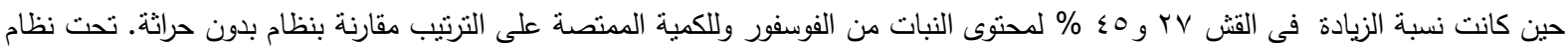

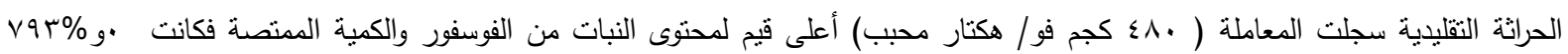

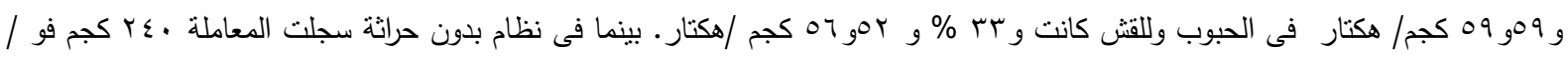

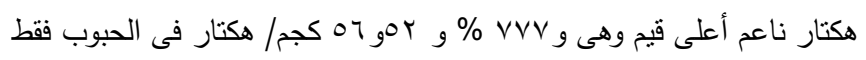

